\title{
What Causes Children to Work in Indonesia?
}

\author{
Heri SANDRA ${ }^{1}$, M. Shabri Abd. MAJID ${ }^{2}$, Taufiq C. DAWOOD ${ }^{3}$, Abdul HAMID ${ }^{4}$ \\ Received: August 01, 2020 Revised: September 20, 2020 Accepted: October 05, 2020
}

\begin{abstract}
This study contributes to the existing literature by empirically exploring the causes of child labor in the Indonesian labor market. Factors identified include rate of poverty, average wages, education participation, and quality of education. This study utilized an aggregate data of 301 districts and cities across 34 provinces sourced from the National Labor Force Survey and the National School/Madrasah Accreditation Board of the Republic of Indonesia. Using a multiple regression analysis, the study found strong evidence of the positive effect of poverty on child labor. Conversely, the study documented the adverse impact of average wages on child labor in Indonesia. Similarly, the participation in the education system also contributed negatively to the child labor. Finally, the quality of education services is found to have a negative effect on child labor in Indonesia. The findings of this study suggest that, in efforts to reduce the involvement of children in the workforce, the poverty eradication program should be enhanced. The wages should be continuously improved, at least, in par with the changes in prices. Finally, the quality of education and its services ought to be further enhanced to attract more child student participation rates across junior high schools nationwide.
\end{abstract}

Keywords: Poverty Reduction, Minimum Wages, School Accreditation, School Participation Rate, Child Labor Policy

JEL Classification Code: J13, J21, I21

\section{Introduction}

Children today are the nation's leaders of the future. Thus, children must be properly cared for so that they can grow with a good of life, physically, mentally, and spiritually. Childhood is filled with learning, playing, and getting to know new things without having to be burdened with responsibilities as adults. In fact, there are still many children who have to work to earn money to support

${ }^{1}$ First Author. Faculty of Economics and Business, Universitas Syiah Kuala and Badan Pusat Statistik (BPS), Padang Pariaman Regency, West Sumatera, Indonesia. Email: heri18@mhs.unsyiah.ac.id

${ }^{2}$ Corresponding Author. Department of Economics, Faculty of Economics and Business, Universitas Syiah Kuala, Indonesia [Postal Address: Darussalam, Banda Aceh, 23111, Indonesia] Email: mshabri@unsyiah.ac.id

${ }^{3}$ Lecturer, Faculty of Economics and Business, Universitas Syiah

Kuala, Indonesia. Email: taufiq.dawood@unsyiah.ac.id

${ }^{4}$ Lecturer, Faculty of Islamic Economics and Business, Islamic State

Institute of Langsa, Aceh, Indonesia.

Email: abdulhamid@febi.iainlangsa.ac.id

(c) Copyright: The Author(s)

This is an Open Access article distributed under the terms of the Creative Commons Attribution Non-Commercial License (https://creativecommons.org/licenses/by-nc/4.0/) which permits unrestricted non-commercial use, distribution, and reproduction in any medium, provided the original work is properly cited. themselves or their families, thus sacrificing their childhood rights. The International Labor Organization (ILO) estimated that over the 2012-2016 period, there were 218 million working children globally, 152 million of whom were child workers. Of concern, there were 72 million of these children doing dangerous work for themselves and their future (ILO, 2017). Criteria for hazardous work are work that physically, sexually and psychologically abuses children, works with dangerous equipment, substances, processes and place, and works too long (ILO, 1999).

Meanwhile, the percentage of global child labor, according to ILO estimates, was $9.6 \%$, but varies in different countries. There were $19.4 \%$ of child labor in lowincome countries $(2015$ Gross National Income per capita USD 1,045 or less), $8.5 \%$ in lower-middle-income countries (2015 GNI per capita USD1,046-4,125), 6.6\% in uppermiddle-income countries (2015 GNI per capita USD4,126$12,735)$, and $1.2 \%$ in high-income countries (2015 GNI per capita USD12,736+). Indonesia was classified as a lower-middle-income country during the global estimation period. The percentage of Indonesian child labor was 2.99\% (Central Bureau of Statistics, Republic of Indonesia, 2009). Meanwhile, based on the 2018 National Labor Force Survey (Central Bureau of Statistics, the Republic of Indonesia, 2018), Indonesian child labor for the four years, from 2011 
to 2014 was $4.23 \%, 4.17 \%, 2.85 \%$, and $2.77 \%$., respectively. The ILO estimation methods and surveys conducted by Central Bureau of Statistics, Republic of Indonesia, may differ, and whether the percentage of Indonesian child labor is above or below the global average may also be inappropriate. However, what needs our attention is that the number of Indonesian child workers is still large, which is bad for both the short- and the long-term future. Thus, continuing efforts need to be made to reduce the occurrence of child labor in the economy if it could not be fully eliminated.

There has been evidence of adverse impacts of child labor on the economy, such as the findings by Kambhampati and Rajan (2006) and Swaminathan (1998). However, more evidence of the negative impact of child labor on the economy has been found. Of the 25 studies reviewed by Ibrahim et al. (2019), child workers are documented to be detrimental to their health. In the shape of weak economic growth, it causes malnutrition, incidence of infectious diseases, higher system-specific diseases, behavioral and emotional disorders, and decreased coping abilities (ability to solve problems and adapt to changes) of the child labor. Posso (2019) and Nelson and Quiton (2018) also found adverse effects of child labor on children's health. Meanwhile, in the long run, former child workers have lower human capital because of less time spent on learning during the childhood (Chakraborty \& Chakraborty, 2018). The hourly earnings of former child labor as adults are much lower, Posso (2017), which reinforces the hypothesis that child labor can inhibit children's cognitive development and are clearer when children reach full maturity.

In terms of education, child labor is negatively related to school enrollment rates in 30 low- and middle-income countries, especially for family work and domestic work (Putnick \& Bornstein, 2015). The increase in child labor is in line with the rise in dropout rates in China (Tang et al., 2018), while Nelson and Quiton (2018) found that dropout rates decreased when the number of hours worked and the frequency of heavy physical workers decreases. He (2016) and Le and Homel (2015) found that child labor harms children's academic achievement. The negative impacts of child labor underlines the importance of research on child labor as a reference in the effort to eliminate the practice.

Referring to the Law No. 13 of 2003 of the Republic of Indonesia concerning the Workforce, a child is any person who is under 18 years of age. Child labor refers to the ILO's definition of "What is child labor?" It refers to work that deprives children of their childhood, their potential and dignity, and that is harmful to their physical and mental development (ILO, 2019). However, the measurement of child labor may differ between researchers depending on what aspects of the work indicator are considered to represent the definition of child labor. This is because of the vast dimensions of work that are considered "depriving children of their childhood".
There have been several studies on child labor. Webbink et al. (2015) studied the number of hours children in Africa and Asia were involved in paid child labor from data on 169,000 children living in 16 countries. They found variations in children's work hours to get wages, mainly due to household-level factors with poverty still a major driving factor. Similarly, Hamenoo et al. (2018) found that poverty is one of the main reasons for children to work in Ghana. Akarro and Mtweve (2011) surveyed 300 households in the Njombe district of Tanzania and found that household poverty is a factor that forces children to engage in economic activity; Naeem et al. (2011) and Fithriani (2012) also found that poverty affects child labor. When households suffer from poverty, the prohibition of child labor is ineffective.

In contrast, using pond ownership as an indicator of wealth, Bhalotra and Heady (2003) found that wealth was positively related to child labor in Pakistan and Ghana. Basu et al. (2010), using land ownership as an indicator of wealth, found that land wealth causes an increase in child labor, but would again decrease when households already have four acres (approximately 1.6 ha) or more land. Thus, they concluded that the relationship of land wealth with child labor is a U-shape. Another study conducted by Lima et al. (2015), using indicators of land ownership as wealth, found that land wealth is precisely in line with the increase in child labor, so that they hypothesizes that parental preferences drive the so-called "wealth paradox" in child labor. Informed by these different empirical findings, this study intends to provide empirical evidence of the effect of poverty on child labor in Indonesia.

Menon and Rodgers' (2018) empirical research in India includes domestic work as an indicator of child labor. They found that, except for rural boys, an increase in adult minimum wages had a positive effect on reducing the household workload of children aged 10-14 years old. But the increase in the minimum wage has no impact on child labor outside the home. In the case of India, Ahmad (2012) found descriptively that child labor thrives in areas with low quality of essential social services, such as education and care. Canagarajah and Coulombe (1999) found a significant negative relationship between children's participation in school and work, besides the high cost of schooling and deficient quality and irrelevance of education also encouraged many children to work. A better education quality is a key driver to the economic development (Le at al., 2020).

Previous studies have examined poverty rates, wage levels, schooling participation, education, and poverty as the common factors affecting child labor. However, those studies rarely measure the relationship between the quality of education services and child labor, as discussed in this study. The quality of education services is one of 
the considerations in determining the educational institution to be attended. Schools with excellent service quality tend to be preferred by the students. Bae (2007) found that the quality of educational services (as measured by International Organization for Standardization, ISO 9000) is positively related to the level of school attendance of students in primary and secondary schools. In line with this, Jensen and Nielsen (1997) found descriptively that the poor quality of schools is an important reason why children do not go to school. The quality of education services is a form of guarantee that the implementation of the education process can run following the expected quality. In the Indonesian national education system, the quality standard of education services is determined in the form of accreditation. Accreditation assessment includes educational inputs, processes, outputs, and outcomes. At the school/madrasah level, there are eight standards used in the accreditation assessment, namely, the content, process, graduate competencies, educators and education personnel, facilities and infrastructure, management, financing, and education assessment standards (The National School/ Madrasah Accreditation Board, 2019). Each of these standards is given a score per the condition of the school/ madrasah assessed. The results of this accreditation will be issued in the form of ratings according to the levels of schools' accreditation, namely, A (Excellent), B (Good), C (Moderate). In contrast, schools/madrasah that do not meet the minimum level are not accredited (The National School/ Madrasah Accreditation Board, 2019).

In addition, research on child labor has commonly utilized micro-data at the household level (Tang et al., 2018; Menon \& Rodgers, 2018; Posso, 2017; Webbink et al., 2015; Ali \& Arabsheibani, 2017). To the best of our knowledge, none of the previous studies has used macro-data for the case of Indonesia. Thus, to fill the existing gaps in the earlier studies, this study utilizes macro data of 301 districts and cities across 34 provinces Indonesia to determine the influence of poverty rate, average wages for adult workers, school participation rates, and quality of education services on the child labor. The findings of this study should shed some lights for policymakers in designing regulation to protect child workers from exploitation. Besides, the results of the study are also expected to be beneficial for the government to use as reference in improving education quality and its services so that it becomes more attractive for children to attend the schools.

\section{Research Methods}

This research uses data from the National Labor Force Survey (Central Bureau Statistics of the Republic of Indonesia) and the National School/Madrasah Accreditation Board. Child labor data used is the percentage of child labor in the districts/cities in Indonesia. School participation rates indicate the percentage of the population of certain school-age groups who are in school (regardless of the level of education pursued) of the population of the corresponding school age group. Because the analyzed child labor data are children aged 11-17 years, the school participation rate in this study also uses children's school participation in that age range in districts/cities in Indonesia. Average wages are the average wages received by adult workers for a month, both workers who are workers, employees, and free workers. These three data sets were obtained through data processing from National Labor Force Survey (Central Bureau of Statistics, 2018). The percentage of the poor population shows the proportion of poor people in the districts/cities, which is the population whose monthly per-capita consumption is below the poverty line. Data on the percentage of the poor population is obtained from the publication of the Central Bureau of Statistic digital data. Data on the quality of education services in this study is the percentage of schools across the districts/cities in Indonesia that are at least accredited B (Good) category, obtained from the National Accreditation Board for Schools/ Madrasah

Due to data limitation, we can only use data from 301 districts/cities in Indonesia. However, the selected data represents all districts/cities from each province nationwide. This study uses the Ordinary Least Square (OLS) method. This method has some interesting statistical properties that make it one of the most powerful and popular regression analysis methods (Gujarati \& Porter, 2009). By applying classical linear assumptions, the OLS method is expected to produce an estimator that is not biased, is linear, and has a minimum variant (Best Linear Unlimited Estimator - BLUE). The OLS equation model estimated in this study is as follows:

$$
C H L=\beta_{0}+\beta_{1} P O V+\beta_{2} W G E+\beta_{3} S P R+\beta_{4} A C R+\varepsilon
$$

where $C H L$ is the number of child labor, $P O V$ is the percentage of poverty, $W G E$ is the average wage of workers, $S P R$ is the school participation rate, $A C R$ is the accreditation of the schools, $\beta_{0}$ is the constant term, $\beta_{1}, \beta_{2}$, $\beta_{3}$, and $\beta_{4}$ are estimated regression coefficients, and $\varepsilon$ is the error term.

Before the data is further analyzed, a classical assumption test will be performed first. The multicollinearity test is used to ensure there is no perfect linear relationship between some or all independent variables (Majid \& Mahrizal, 2017). Heteroskedasticity test is conducted to find out whether there is a variance in the residual variance for all observations in the regression model (Yusof \& Majid, 2007). The normality test is performed to identify whether the residual value is normally distributed. The statistical software of E-Views is utilized to analyze the data. 


\section{Results and Discussion}

Based on the data from the National Labor Force Survey (Central Bureau of Statistics, 2018), the study found that the percentage of Indonesian child labor was $3.77 \%$. As for the provincial level, there were 12 provinces where the average number of child workers is higher than the national average, and most of them are provinces in the Eastern part of Indonesia, such as Nusa Tenggara, Sulawesi (except for North Sulawesi) and Papua. These results confirmed the published data on the Indonesian Child Profile 2018 from the Indonesian Ministry of Women's Empowerment and Child Protection, which shows that there were a large number of working children in these provinces (Windiarto, 2018).

What is the cause of a large number of child labor across the provinces in Indonesia? This is an old unresolved issue, thus still relevant to be further explored in this study. However, based on previous studies, some macroeconomic indicators of welfare in these provinces appear to be unfavorable when compared to the Indonesian national average. As illustrated in Figure 1, except for South Sulawesi, which has a poverty rate of $8.87 \%$, the poverty rate in these provinces is higher than the national poverty rate of only $9.66 \%$ in the second half of 2018 (Papua $27.43 \%$, West Sulawesi 11.22\%, Gorontalo 15.83\%, Gorontalo 15.83\%, Southeast Sulawesi 11.32\%, Central Sulawesi 13.69\%, NTT $21.03 \%$, NTB 14.63\%) (Central Bureau of Statistics, 2019a).

Meanwhile, human capital in these provinces is much lower than the national average. Human Development
Index (HDI) of Papua was 60.06, West Sulawesi was 65.10, Gorontalo was 67.71, Southeast Sulawesi was 70.61, South Sulawesi was 70.90, Central Sulawesi was 68.88 , NTT was 64.39 , and NTB was 67.30 , while the Indonesian HDI was 71.39 (Central Bureau of Statistics, 2019b). Except for School Participation Rate (SPR) for ages 13-15 years in NTB, SPR in these provinces is lower than the national average (95.36). SPRs in Papua was 80.00, West Sulawesi was 89.95, Southeast Sulawesi was 94.29, Gorontalo was 91.38, South Sulawesi was 93.13, Central Sulawesi was 92.74, and NTT was 94.95 (Central Bureau of Statistics, 2019c). These provinces certainly need more attention from the government. North Sulawesi and DKI Jakarta were the provinces that experienced a low percentage of child labor. Before analyzing the proposed regression model, Table 1 presents the results of the classical assumption tests.

In the normality testing, Jarque-Berra probability is $0.154078>0.05$, which means that there is enough evidence to say that the residues in the model are normally distributed. Chi-Square probability value from the White test of 0.3108 is higher than 0.05 . Thus, this provides evidence of the inexistence of heteroskedasticity in the model. Centred Variance Inflation Factors (VIF) of each independent variable is less than 10 , so there is evidence of no perfect linear relationship existed between the independent variables (non-multicollinearity). The results of the test provide proof that the model has met the classical assumptions so that the model is expected to produce an estimator that is not biased, linear and has minimum variance (Best Linear Unlimited Estimator - BLUE).

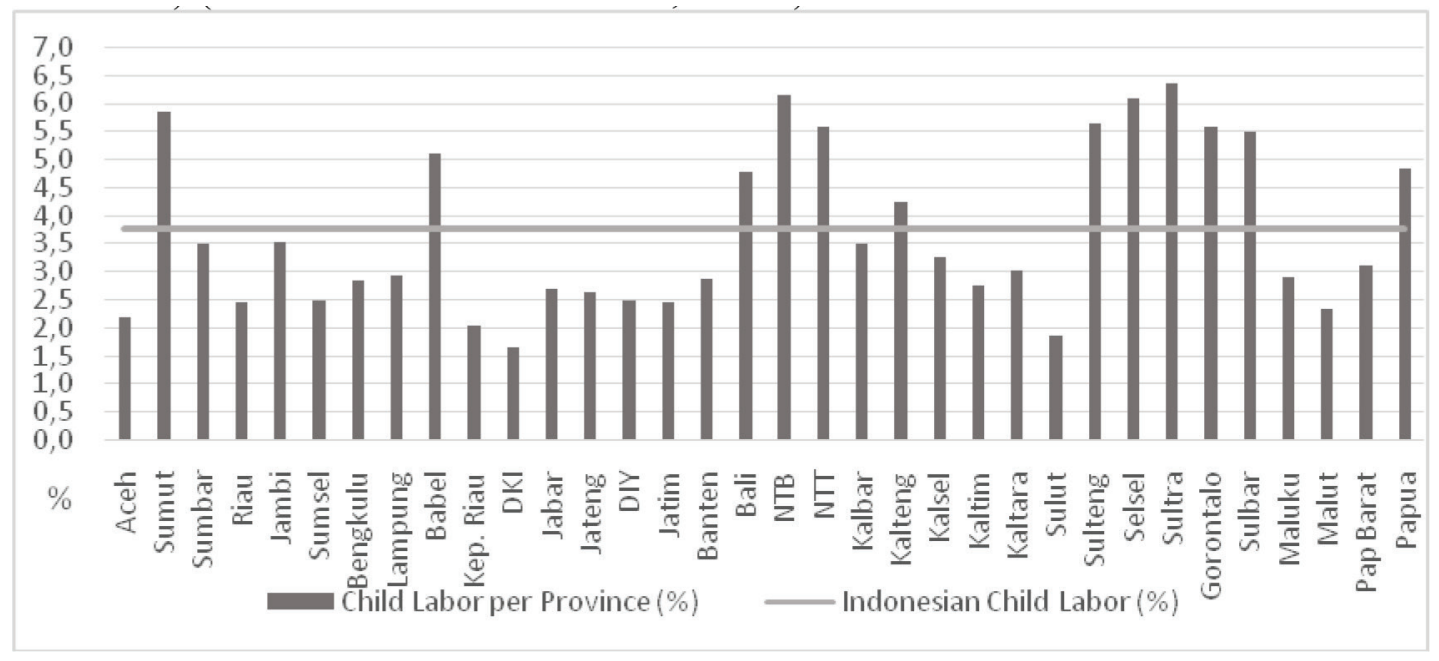

Source: The National Labor Force Survey (Central Bureau of Statistics, 2018), data processed.

Figure 1: Percentage of Child Labor by Province 
Table 1: The Classical Assumption Test Results

\begin{tabular}{|l|c|c|c|}
\hline \multicolumn{1}{|c|}{$\mathbf{N}$} & Test & P-value \\
\hline Dependent Variable: CHL \\
\hline Series residual & 301 & & \\
\hline Jarque-Berra & & 5.9539 & 0.0509 \\
\hline White & 301 & & \\
\hline Obs*R-square & & 21.0292 & 0.1009 \\
\hline $\begin{array}{l}\text { Variance Inflation } \\
\text { Factors }\end{array}$ & 301 & $\begin{array}{c}\text { Coefficient } \\
\text { Variance }\end{array}$ & $\begin{array}{c}\text { Centred } \\
\text { VIF }\end{array}$ \\
\hline POV & & 0.0001 & 1.2708 \\
\hline WGE & & 1.2708 & 1.0269 \\
\hline SPR & & 0.0003 & 1.0864 \\
\hline ACR & & 0.0000 & 1.2399 \\
\hline C & & 13.2705 & n.a \\
\hline
\end{tabular}

Table 2: OLS Regression Results

\begin{tabular}{|l|c|c|c|}
\hline Variable & $\begin{array}{c}\text { Estimated } \\
\text { Coefficient }\end{array}$ & t-Statistic & P-value \\
\hline POV & $0.0370^{* * *}$ & 3.4616 & 0.0006 \\
\hline WGE & $-0.9375^{* * *}$ & -4.1620 & 0.0000 \\
\hline SPR & $-0.2280^{* * *}$ & -13.9779 & 0.0000 \\
\hline ACR & $-0.0089^{* * *}$ & -2.5745 & 0.0105 \\
\hline C & $38.5091^{* * *}$ & 10.5711 & 0.0000 \\
\hline \multicolumn{4}{|c|}{ Adj-R ${ }^{2}=0.5214 ;$ F-stats. $=80.62481 ;$} \\
\hline \multicolumn{4}{|c|}{ F-stats (p-value) $=0.0000$} \\
\hline
\end{tabular}

Note: ${ }^{* *}$ indicates significance at the $1 \%$ level.

After ensuring all the variables fulfilled the classical assumptions, the proposed model of the OLS is estimated, and its findings are reported in Table 2. As illustrated in Table 2, the goodness of our estimated model can be identified through the significance of F-statistic in Table 2. Its p-value of 0.0000 provides evidence that simultaneously, the independent variables influence the dependent variables; thus, the analysis of this model can further proceed. The magnitude of the influence of the independent variable explains the dependent variable can be seen simultaneously through the estimated value of the coefficient of determination, Adjusted $\mathrm{R}^{2}$ of 0.5214 . By referring to this value, the variables of poverty, wages, school participation rates, and the quality of education services can explain variations in child labor by $52.14 \%$. In comparison, the rest $47.86 \%$ is explained by other variables not included in this study.

Based on the findings from Table 2, the results of the OLS regression can be presented, as follows:

$$
\begin{aligned}
C H L & =38.5091+0.0370 P O V-0.9375 W G E-0.2280 S P R \\
& -0.0089 A C R
\end{aligned}
$$

Based on the results of the estimated regression model, child labor is significantly related to poverty, adult worker wages, school participation rates, and the quality of education services. This empirical evidence can be viewed from the $\mathrm{p}$-value of the estimated independent variable, which is less than $1 \%$. By looking at the estimated coefficients of each variable, the magnitude of the effect of each independent variable on child labor can be identified.

Poverty is positively and significantly related to child labor, where an increase of $100 \%$ of the poverty rate has caused a rise in $3.70 \%$ of child labor. These results confirm the findings of Hamenoo et al. (2018), Nwazuoke and Igwe (2016), Webbink et al. (2015), Naeem et al. (2011), and Akarro and Mtweve (2011) who found poverty as the primary driver of child labor. Poor households are characterized by their lack of ability to meet their needs. The head of the family and other adults should try to work to meet those needs. But if it is not fulfilled, the participation of children in economic activities is to help fulfill the needs of the household. At least the children will get additional income for themselves to meet their needs, such as extra pocket money, personal needs, school needs, and other daily household needs.

The situation of poor households sometimes also confronts children with the choice of school or work. When children are attending schools, parents have to finance them. At the same time, they lose opportunities to earn extra income for households. If conditions are hard, children in low-income families do not attend formal education; instead, they join the labor force, as a positive activity they can do. Even though working, there is not much additional income that children can earn due to a lack of skills, energy, and experience. Children who work may only be able to do part of what adults can do (substitution axiom) as well as in obtaining wages or income. Another alternative is for children to combine school and work. School is conducted in the morning and works in the afternoon or evening. But this is undoubtedly very difficult for children because they have to do two activities. They must focus on understanding lessons at school as well as earning income.

Unlike the poverty rate that affected child labor positively, the wage rate, school participation rate, and school accreditation are found to have a significant adverse effect on child labor. An increase in the wages of adult workers has caused a decline in child labor. More specifically, an increase of $10 \%$ in the average salary of adult workers has caused a 
decrease of $93.75 \%$ of child labor. This finding is in harmony with the luxury axiom by Basu and Van (1998) according to which children enter the labor market if income from sources other than child labor falls drastically. Basu and Van (1998) provide two balances of child labor and adult labor in an economy that are both stable. First, adults and children work together at low wages, also called bad balance. It is said to be bad because this balance is only reached when children come to work. Second, only adults work with high wages, this is called as a good balance because children avoid working. The measure of high wages in this analysis is that adult wages are above the level of subsistence. In this position, parents have no reason to send children to work. But when the balance is bad, where the adult wages are low (below the subsistence level), parents send their children to work to maintain the fulfillment of their household needs. As for the adult salary level above subsistence, parents voluntarily withdraw their children from the workforce.

The data from the National Labor Force Survey (Central Bureau of Statistics, 2018) showed that more than half the working population $(57.4 \%)$ is workers (employees/ laborers/casual workers/family workers) and the rest were self-employed or tried to be assisted by workers. This fact shows that more of the working population expects income in the form of wages. The level of wages affects the fulfillment of their household needs. The higher the wage level, the greater their ability to meet household needs. When household needs are met, children are likely to become child labor. Besides, children who are already working can be pulled out. Thus, the level of wages follows the decline in child labor in Indonesia.

Table 2 also shows strong evidence that children's participation in the world of formal education has reduced child labor. A $10 \%$ increase in school participation rates is associated with a reduction of $22.80 \%$ of child labor. The presence of children at school reduces their time to work. Besides, their presence at school makes the fulfillment of children's rights to education. School participation is also a form of awareness of the importance of education. The presence of children in education may reduce the potential for additional short-term income from the household if the child works. But with education, it provides a higher return in the future than they work too early (Posso, 2017). If the household is aware of it, of course, participating in education is the best choice for children.

Finally, the study also found a significant adverse effect on the quality of education services (school accreditation) on child labor. An increase of $100 \%$ in the quality of education services which states the percentage of schools accredited at least Good (B) category in the Regency/City has reduced $0.89 \%$ of child labor in Indonesia. The quality of education services is an indicator to represent the services delivered by educational institutions following expected standards.
This quality also becomes one of the factors of the child and his parents in choosing educational institutions. Children certainly prefer schools with better service quality. On the other hand, improving the quality of educational services caused an increase in the attendance of children at school (Bae, 2007) and limited them to work. This finding is also supported by Canagarajah and Coulombe (1999), who found a negative effect of education quality and the number of child labor.

\section{Implications}

Based on our findings, the study offers several implications and recommendations. Government efforts in implementing compulsory education programs need to be supported to increase children's school participation. Implementation of this program has not been maximized, especially for children 16-17 years. The data from the Central Bureau of Statistics, the Republic of Indonesia (2018) shows the involvement of school children at this age range in 2018 is only $71.99 \%$. This finding indicates that there is still $28.01 \%$ of children in that age range who are not in school for various reasons. Their absence from education caused them to carry out other activities, both negative and positive, and work is the most favorable activity they are likely to do.

Furthermore, the government needs to continuously strive to improve the quality of educational services to increasing the presence of school children that, in turns, reduces child labor. Aspects that need attention in improving this quality are the content standards, processes, competencies of educators and education personnel, competencies of graduates, facilities and infrastructure, management, financing, and education assessment standards (Kumari, 2014). It should also be noted that, based on data from the National Labor Force Survey (Central Bureau of Statistics, 2018), the majority (53.4\%) of child labor were children who are active in school. They functioned both as students and economic actors. Improving the quality of education services can at least make the portion of their functions as students can be higher than the economic agents.

Efforts to ban child labor must be continued. There is an arrangement/protection for children who work by the Indonesian government as stipulated in Articles 6875 of the Law No. 13 of 2003 concerning Manpower. The implementation of this rule is more easily enforced in the formal sectors because there are interests of employers to protect their employees, including child labor following the applicable labor protection standards. However, the majority of workers $(95.2 \%)$ in the Indonesian labor market are involved in the informal sectors, including micro- and small-scale businesses, home-based businesses, and so on. Thus, more serious efforts and close monitoring are needed to ensure the implementation of such labor rules. 
The efforts become more effective if households are not living in poverty. Poor parents might force their children to work, while prosperous parents would prohibit their children from working. Parents can voluntarily withdraw their children from the workplace when their well-being increases (Basu \& Van, 1998). Thus, poverty eradication becomes a fundamental way to prevent child labor. Poverty alleviation and increased children participation in schooling are closely related. Thakurata and D'Souza (2018) found that uneducated households choose assets with a negative return on investment in human capital in their offspring. Because they fall into the intergenerational poverty trap, their educational investment begins once their income passes the threshold level.

Increasing the wages of adult workers promotes households' income, help them stay away from poverty, and, in turns, prevent children from working. The study documented a significant effect of adult worker wages on reducing child labor; thus, it is pivotal for the government to increase workers' salaries, at least, at par with the inflation rate. However, the design of wage policy should be carefully assessed and reviewed, as it involved the interest of employers. If the regulated salary is too high, it will be burdensome to employers. In contrast, if it is too low, it is insufficient for the labor to meet their basic needs, and put them under the poverty trap. Local labor policy should be designed in the favor of both child labor and business entity (Hoang \& Nguyen, 2020). Households that earned less income might allow and even forced their children to work (Basu, 2000).

\section{Conclusions}

This research contributes to child labor literature by presenting empirical evidence of the impact of poverty and education on child labor in Indonesia. Using an Ordinary Least Square regression and aggregate data of 301 districts/ cities across Indonesia nationwide, the study documented strong evidence of a significant positive relationship between poverty rate and the child labor. In contrast, the wage for adult workers, school participation rates, and the quality of education services were significantly and negatively related to child labor. Therefore, efforts to reduce poverty need to be continuously implemented and strengthened in line with efforts to increase the wages of adult workers (Dewi et al., 2028; Majid et al., 2019). A 12-year compulsory education program to be attended by the children in Indonesia needs to be continuously supported and improved to ensure children's school participation. This national education policy needs to be accompanied by an increase in the quality of education and schools' services.

By paying attention to the estimated value of the coefficient of determination, the investigated determinants in this study only explained about half of the variations in the child labor in Indonesia. Thus, further research should include more determinants of child labor, such as social-, cultural-, political-, environmental-, and technological-related factors in their analyses. Comparative studies of determinants of child labor across ASEAN countries and other regional economies could also enrich the existing empirical evidence on child labor worldwide.

\section{References}

Ahmad, A. (2012). Poverty, education and child labor in Aligarh City-India. Studies on Home and Community Science, 6(3), 165-172. https://doi.org/10.1080/09737189.2012.11885382.

Akarro, R. R. J., \& Mtweve, N. A. (2011). Poverty and its association with child labor in Njombe District in Tanzania: The case of Igima ward. Research Journal of Social Sciences, 3(3), 199-206.

Ali, D. H. B. A., \& Arabsheibani, G. R. (2017). Child labor in Indonesia: Supply-side determinants. Economics and Finance in Indonesia, 62(3), 162. https://doi.org/10.7454/efi.v62i3.555.

Bae, S. H. (2007). The relationship between ISO 9000 participation and educational outcomes of schools. Quality Assurance in Education, 15(3), 251-270. https://doi.org/http://dx.doi.org /10.1108/09684880710773156.

Basu, K. (2000). The intriguing relation between adult minimum wage and child labor. The Economic Journal, 110(462), C50-C61.

Basu, K., Das, S., \& Dutta, B. (2010). Child labor and household wealth: Theory and empirical evidence of an inverted-U. Journal of Development Economics, 91(1), 8-14. https://doi.org /10.1016/j.jdeveco.2009.01.006.

Basu, K., \& Van, P. H. (1998). The economics of child labor. American Economic Review, 88(3), 412-427. https://doi. org/10.1257/aer.89.5.1386.

Bhalotra, S., \& Heady, C. (2003). Child farm labor: The wealth paradox. The World Bank Economic Review, 17(2), 197-227. https://doi.org/10.1093/wber/lhg017

Canagarajah, S., \& Coulombe, H. (1999). Child labor and schooling in Ghana. Washington, DC: The World Bank. https://doi.org /10.1596/1813-9450-1844.

Central Bureau of Statistics, the Republic of Indonesia. (2009). Child Labor in Indonesia, 2009. Jakarta: BPS.

Central Bureau of Statistics, the Republic of Indonesia. (2018). Survey of National Labor Force 2018. Jakarta, Indonesia: BPS.

Central Bureau of Statistics, the Republic of Indonesia. (2019a). Percentage of Poor People by Province, 2007-2019. Retrieved October 1, 2019, from https://www.bps.go.id/ dynamictable/2016/08/18/1219/ persentase-penduduk-miskinmenurut-provinsi-2007-2019.html.

Central Bureau of Statistics, the Republic of Indonesia. (2019b). Human Development Index by Province, 2010-2018 (New Method). Retrieved October 1, 2019, from https://www.bps. 
go.id/dynamictable/2016/06/ 16/1211/indeks-pembangunanmanusia-menurut-provinsi-2010-2018-metode-baru-.html.

Central Bureau of Statistics, the Republic of Indonesia. (2019c). School Participation Rate by Province, 2011-2018. Retrieved October 1, 2019, from https://www.bps.go.id/ dynamictable/2015/12/22/ 1054/angka-partisipasi-sekolahapsmenurut-provinsi-2011-2018.html.

Chakraborty, K., \& Chakraborty, B. (2018). Low-level equilibrium trap, unemployment, efficiency of education system, child labor and human capital formation. Journal of Economics/Zeitschrift Fur Nationalokonomie, 125(1), 69-95. https://doi.org/10.1007/ s00712-017-0585-x.

Dewi, S., Majid, M. S. A., Aliasuddin., \& Kassim, S. (2018). Dynamics of financial development, economic growth, and poverty alleviation: The Indonesian experience. South East European Journal of Economics and Business, 13(1), 17-30. https://doi.org/10.2478/jeb-2018-0002

Fithriani, R. (2012). Child labor, poverty, and economic value of children: Case study of Lampung Province 2011. Proceedings of Child Poverty and Social Protection Conference (pp. 1-20). Jakarta, Indonesia, September 10-11. Jakarta, Indonesia: SMERU

Gujarati, D. N., \& Porter, D. C. (2009). Basic Econometrics (5th ed.). New York, NY: McGraw Hill Inc.

Hamenoo, E. S., Dwomoh, E. A., \& Dako-Gyeke, M. (2018). Child labor in Ghana: Implications for children's education and health. Children and Youth Services Review, 93(4), 248254. https://doi.org/10.1016/ j.childyouth.2018.07.026.

He, H. (2016). Child labor and academic achievement: Evidence from Gansu Province in China. China Economic Review, 38(2), 130-150. https://doi.org/10.1016/j.chieco.2015.12.008.

Hoang, L. K., \& Nguyen, K.T. (2020). Fuzzy-AHP application in analyzing the factors affecting quality of rural labor. Journal of Asian Finance, Economics and Business, 7(8), 715-721. https://doi.org/10.13106/jafeb.2020. vol7.no8.715

Ibrahim, A., Abdalla, S. M., Jafer, M., Abdelgadir, J., \& De Vries, N. (2019). Child labor and health: A systematic literature review of the impacts of child labor on child's health in low- and middle-income countries. Journal of Public Health, 41(1), 18-26. https://doi.org/10.1093/pubmed/fdy018.

ILO. (1999). The Worst Forms of Child Labor Recommendation, No. 190, 1-27.

ILO. (2017). Global Estimates of Child Labor: Results and Trends, 2012-2016. Retrieved January 5, 2020, from https:// doi.org/10.1016/j. soilbio.2011.02.006.

ILO. (2019). What is Child Labor? Retrieved October 1, 2019, from https://www.ilo.org /ipec/facts/lang--en/index.htm.

Jensen, P., \& Nielsen, H. S. (1997). Child labor or school attendance? Evidence from Zambia. Journal of Population Economics, 10(4), 407-424. https://link.springer.com/ article/10.1007/ s001480050051.

Kambhampati, U. S., \& Rajan, R. (2006). Economic growth: A panacea for child labor? World Development, 34(3), 426-445. https://doi.org/10.1016/j.worlddev.2005.08.010.
Kumari, N. (2014). Most to least preferred parameters affecting the quality of education: Faculty perspectives in India. Journal of Asian Finance, Economics and Business, 1(3), 3742. https://doi.org/10.13106/jafeb.2014. vol1.no3.37.

Le, Q. T. T., Doan, T. H. D., Nguyen, Q. L. H. T. T., \& Nguyen, D. T. P. (2020). Competency gap in the labor market: Evidence from Vietnam. Journal of Asian Finance, Economics and Business, 7(9), 697-706. https://doi.org/10.13106/jafeb.2020. vol7.no9.697

Le, H. T., \& Homel, R. (2015). The impact of child labor on children's educational performance: Evidence from rural Vietnam. Journal of Asian Economics, 36(2), 1-13. https:// doi.org/10.1016/j.asieco.2014.11.001.

Lima, L. R., Mesquita, S., \& Wanamaker, M. (2015). Child labor and the wealth paradox: The role of altruistic parents. Economics Letters, 130(2), 80-82. https://doi.org/10.1016 /j.econlet.2015.03.005.

Majid, M. S. A., \& Mahrizal, M. (2007). Does financial development cause economic growth in the ASEAN-4 countries? Savings and Development, 31(4), 369-398.

Majid, M. S. A., Dewi, S., Aliasuddin., \& Kassim, S. H. (2019). Does financial development reduce poverty? Empirical evidence from Indonesia. Journal of the Knowledge Economy, 10(3), 1019-1036. https://doi.org/10.1007/s13132017-0509-6

Menon, N., \& Rodgers, Y. Van Der M. (2018). Child labor and the minimum wage: Evidence from India. Journal of Comparative Economics, 46(2), 480-494. https://doi. org/10.1016/j.jce.2017.09.001.

Naeem, Z., Shaukat, F., \& Ahmed, Z. (2011). Child labor in relation to poverty. International Journal of Health Sciences, 5(2), 48-49. Retrieved June 12, 2019, from https://www.ncbi. nlm.nih.gov/pmc /articles/PMC3533357/.

Nelson, G. L. M., \& Quiton, J. D. (2018). Child labor and its effects on schooling, health and recreation of Filipino children. Journal of Population and Social Studies, 26(1), 68-82. https://doi.org/10.25133/ JPSSv26n1.006.

Nwazuoke, A. N., \& Igwe, C. A. (2016). Worst forms of child labor in Nigeria: An appraisal of international and local legal regimes. Beijing Law Review, 7(1), 69-82. https://doi. org/10.4236/blr.2016.71008.

Posso, A. (2017). Child labor's effect on long-run earnings: An analysis of cohorts. Economic Modelling, 64(1), 465-472. https://doi.org/10.1016/j.econmod. 2017.02.027.

Posso, A. (2019). The health consequences of hazardous and nonhazardous child labor. Review of Development Economics, 23(2), 619-639. https://doi.org/10.1111/rode.12571.

Putnick, D. L., \& Bornstein, M. H. (2015). Is child labor a barrier to school enrollment in low- and middle-income countries? International Journal of Educational Development, 41(2), 112-120. https://doi.org/ 10.1016/j.ijedudev.2015.02.001.

Swaminathan, M. (1998). Economic growth and the persistence of child Labor: Evidence from an Indian City. World 
Development, 26(8), 1513-1528. https://doi.org/10.1016/ S0305-750X(98)00063-1.

Tang, C., Zhao, L., \& Zhao, Z. (2018). Child labor in China. China Economic Review, 51(1), 149-166. https://doi. org/10.1016/j.chieco.2016.05.006.

Thakurata, I., \& D'Souza, E. (2018). Child labor and human capital in developing countries - A multi-period stochastic model. Economic Modelling, 69(2), 67-81. https://doi.org/ 10.1016/j.econmod.2017.09.006.

The National School/Madrasah Accreditation Board. (2019). Accreditation Instruments. Retrieved June 12, 2020, from https://bansm.kemdikbud.go.id/
Webbink, E., Smits, J., \& Jong, E. De. (2015). Child labor in Africa and Asia: Household and contextual determinants of hours worked in paid labor by young children in 16 low-income countries. European Journal of Development Research, 27(1), 84-98. https://doi.org/10.1057 /ejdr.2014.19.

Windiarto, T. (2018). Profile of Children in Indonesia 2018. Jakarta, Indonesia: Ministry of Women's Empowerment and Child Protection of the Republic of Indonesia.

Yusof, R. M., \& Majid, M. S. A. (2007). Macroeconomic variables and stock returns in Malaysia: An application of the ARDL bound testing approach. Savings and Development, 31(4), 449-469. 